\title{
PROGRAM IPTEKS BAGI MASYARAKAT (IbM) PENDIDIKAN DI DESA TERPENCIL
}

\author{
Desak Putu Parmiti, Made Sulastri, I Ketut Pudjawan
}

Universitas Pendidikan Ganesha

\begin{abstract}
ABSTRAK
Kegiatan akhir dari IbM ini adalah (1) terwujudnya 1 paket kurikulum di pesraman Widya Santhi Mandiri dan Sekha Santhi Jayanti Saraswati yang berbasis kewirausahaan, (2) terwujudnya buku penunjang pembelajaran di pesraman, (3) terwujudnya media pembelajaran yang membantu pendidikan di pesraman Widya Santhi Mandiri dan Sekha Santhi Jayanti Saraswati. Dan (4) terwujudnya unit usaha mandiri yang bisa membantu keuangan lembaga. Pesraman widya santhi mandiri adalah salah satu pesraman yang mengembangan seni budaya daerah di Desa Tianyar. Pembelajaran di Pesraman Widya Santhi Mandiri adalah pembelajaran kebudayaan seperti menari, mesatua, mekidung, nulis lontar, membuat banten, dan darma tula dan darma wecana. Sedangkan Sekha Santhi Jayanti Saraswati adalah Kelompok seni suara tradisional yang bergerak di bidang kebudayaan mekidung/meshanti (bernyanyi) untuk orang dewasa. Kelompok ini terdiri dari 30 orang, 10 wanita dan 20 lelaki. Kedua kelompok ini masih terbatas dengan pembelajaran konvensional, tanpa kurikulum, dan media pembelajaran yang digunakan juga belum ada. Walaupun bergerak di pendidikan non formal, kurikulum, proses pembelajaran, dan media pembelajaran tetap memegang peranan penting terhadap keberhasilan siswa. Berdasarkan gambaran dari potret permasalahan yang dihadapi mitra, tolok ukur transfer iptek bagi masyarakat adalah dengan menyasar 30 anak-anak dan 30 orang dewasa perwakilan masing-masing kelompok mengimplementasikan kurikulum yang sudah dirancang. Adapun ilmu pengetahuan dan teknologi yang telah ditransfer adalah: 1) pelatihan penyusunan kurikulum pesraman, 2) Pelatihan pembuatan media pembelajaran penunjang kurikulum, dan 3) Pelatihan manajemen organisasi. Keseluruhan proses transfer iptek yang telah dilaksanakan dengan pola pendidikan dan pelatihan serta pendampingan yang meliputi: sosialisasi, pelatihan, dan pendampingan kepada pesraman Widya Santhi Mandiri dan Sekha Santhi Jayanti Saraswati diharpakan dapat menambah wawasan dan kepribadian output dari pembelajaran yang dilakukan di kedua kelompok tersebut.
\end{abstract}

\section{PENDAHULUAN}

Berbeda dengan pendidikan di kota yang begitu mudah mengakses pendidikan, di daerah terpencil dan termarginalkan seperti di kecamatan kubu terutama daearah Banjar Pedahan dan Muntigunung memiliki banyak persoalan, diantaranya minimnya sarana dan prasarana, kurangnya tenaga pengajar, tidak adanya teknologi informasi dan komunikasi, serta sulitnya akses transportasi. Minimnya akses pendidikan ini sangat berpengaruh terhadap pola hidup masyarakatnya, seperti kurang bersih, petani yang tidak berkembang, mudah dibodohi, dan tidak kreatif, dan lain sebagainya. Hal ini menunjukkan bahwa pemerataan pendidikan dan peningkatan kualitas pendidikan sangat sulit untuk diwujudkan.

Secara geografis, lokasi banjar pedahan dan munti gunung berada di wilayah pegunungan tanah kering dengan medan yang berbukit-bukit. Akes jalan menuju daerah ini masih sulit dilalui sepeda motor. Banjar pedahan berjarak $80 \mathrm{Km}$ dari kota Amlapura (Kota Kabupaten). Banjar pedahan termasuk ke dalam dinas desa Tianyar Tengah dengan jumlah penduduk 1576 KK. Begitu terpencilnya wilayah ini membuat penduduk yang berada di desa ini mata pencaharian hanya bisa sebagai petani kecil bahkan ada yang sampai menggepeng. Musim hujan para petani melakukan cocok tanam sedangkan musim panas melakukan gepeng. Hal ini dapat dilihat bahwa hampir setiap bulan dinas sosial kota Denpasar selalu membina dan mengembalikan gepeng yang berasal dari wilayah Pedahan dan Muntigunung. Selain itu kehidupan masyarakat juga sangat keras, ini ditunjukkan dengan banyak kasus kekerasan dalam rumah tangga, kekerasan seksual, bahkan sampai 
tindakan kriminal. Selain itu, 1 tahun belakangan ini, banyak diterjadi kasus bunuh diri yang diakibatkan karena hal yang sangat sepele, seperti karena tidak dikasi HP seorang siswi SMP kelas 2 melakukan bunuh diri, karena tidak dikasi pacaran seorang siswa kelas 1 SMP melakukan bunuh diri, dan yang paling terbaru adalah adanya bunuh diri karena selalu diejek oleh teman-temanya.

Untuk layanan pendidikan formal, di banjar pedahan sudah terdapat beberapa sekolah formal yakni ada 4 SD dan 1 SMP 1 atap. Sekolah ini sudah ada sejak tahun 1990an. SD yang ada sudah hampir menamatkan 500 siswa, dan 300 siswa DO. Kebanyak siswa berhenti sekolah karena membantu orang tua, diajak ke kota untuk bekerja, minimnnya biaya, jarak rumah dengan sekolah terlalu jauh, dan masyarakat tidak melihat dampak positif antara anak yang bersekolah dengan anak yang tidak bersekolah, sehingga mereka enggan untuk menyekolahkan anaknya. Sedangkan siswa yang tamat SD hanya sebagian kecil yang melanjutkan ke jenjang sekolah menengah pertama. Itu pun melanjutkannya ke sekolah SMP 1 atap. Dimana fasilitas, tenaga pengajar dan proses pembelajarannya sangat kurang.

Walaupun demikian pemerintah telah melakukan berbagai upaya untuk membantu sekolah tersebut diantaranya bantuan sarana dan prasarana dan BOS (Bantuan Operasional Sekolah). Selain itu, berbagai macam pelatihan dan workshop juga pernah dikuti untuk meningkatkan SDM tenga pengajarnya. Namun perkembangan pendidikan untuk anak-anak di banjar tersebut masih sangat lambat. Hal ini ditunjukkan dengan aktivitas masyarakat yang masih suka menggepeng, bolos sekolah, tidak memiliki kemampuan berpikir logis, berpikir kritis, berpikir kreatif, berinisiatif, dan dan tidak adaptif terhadap perubahan dan perkembangan IPTEK.

Melihat pendidikan formal belum memenuhi harapan pemerintah dalam meningkatkan kualitas pendidikan terutama di wilayah pedesaan dan terpencil oleh sebab itu diperlukan pendidikan lain seperti pendidikan non formal untuk membantu percepatan pendidikan di daerah terpencil. Sebenarnya di banjar pedahan dan Muntigunung sudah memiliki lembaga tradisional yang bergerak di pendidikan non formal yang dapat membantu akses dan perkembang pendidikan di wilayah itu. Misalnya Pesraman Widya Santhi Mandiri dan Sanggar Belajar Widya Sari bergerak di bidang pendidikan anak-anak dan remaja yang mengajarkan dan mengembangkan kebudayaan lokal dan keterampilan lokal. Selain itu ada juga, sekhaa santhi-sekhaa santhi (Kelompok seni suara tradisional) yang bergerak di bidang kebudayaan mekidung/meshanti (bernyanyi) untuk orang dewasa. Sekhaa Santhi yang aktif dan rutin melakukan kegiatan adalah Sekhaa Santhi jayanti Saraswati. Pendidikan model ini sudah lama dilakansakana secara turun temurun. Walaupun sudah berdiri sejak lama (1990-an) namun belum mampu membantu meningkatkan perkembangan pendidikan di banjar tersebut. Hal ini disebakan karena kurikulum, media dan proses pembelajaran dalam lembaga tersebut masih bersifat tradisional dan cenderung ketinggalan jaman. Kemampuan tenaga pendidik yang ada belum menjamah pengetahuan dan pendidikan tentang kurikulum, media dan proses pembelajaran.

Pendidikan non formal di wilayah ini sangat besar pengaruhnya terhadap perkembangan SDM anak-anak yang ada disana. Masyarakat lebih senang datang ke lembaga pendidikan non formal dari pada datang ke sekolah. Karena proses pembelajaran di lembaga non formal (khususnya di Pesraman Widya Santhi Mandiri dan Sekhaa Santhi Jayanti Saraswati) dilakukan secara kekeluargaan. Pembelajaran di Pesraman Widya Santhi Mandiri adalah pembelajaran kebudayaan seperti menari, mesatua, mekidung, nulis lontar, membuat banten, dan darma tula dan darma wecana. Selain bergerak di bidang kebudayaan, Pesraman Widya Santhi Mandiri juga aktif dalam memberikan bekal keterampilan dibidang seni lukis dan seni kerajinan. Seni lukis yang dikembangkan adalah seni lukis dengan menggunakan warna alami sedangkan 
seni kerajinan yang dikembangkan adalah kerajinan lontar.

Walaupun bergerak di pendidikan non formal, kurikulum, proses pembelajaran, dan media pembelajaran tetap memegang peranan penting terhadap keberhasilan siswa. Proses pembelajaran di Pesraman Widya Santhi Mandiri dan Skhaa Santhi Jayanthi Saraswati belum menggunakan modelmodel pembelajaran yang inovatif, kreatif, dan menyenangkan. Pembelajaran yang digunakan masih bersifat tranfer pengetahuan, sehingga sisia (siswa)nya menjadi kurang cerdas dan kreatif. Ketika sudah tamat dari pesraman itu, sisia tidak mampu mengembangkan dan mengimplementasikan di luar. Pembelajaran merupakan suatu kegiatan yang melibatkan seseorang dalam upaya memperoleh pengetahuan, keterampilan, dan nilai-nilai positif dengan memanfaatkan berbagai sumber untuk belajar. Dalam sistem pembelajaran modern saat ini, siswa tidak hanya berperan sebagai komunikan atau penerima pesan, bisa saja siswa bertindak sebagai komunikator atau penyampai pesan. Dalam kondisi seperti itu, maka terjadi apa yang disebut dengan komunikasi dua arah atau bahkan komunikasi banyak arah. Dalam bentuk komunikasi pembelajaran manapun sangat dibutuhkan peran media untuk lebih meningkatkan tingkat kefektifan pencapaian tujuan/kompetensi. Artinya proses pembelajaran tersebut akan terjadi apabila ada komunikasi antara penerima pesan dengan sumber/penyalur pesan lewat media tersebut.

Minimnya pengetahuan kurikulum dan media yang digunakan guru selama pembelajaran menyebabkan pembelajaran menjadi membosankan dan atau tidak menyenangkan. Padahal media merupakan salah satu komponen komunikasi, yaitu sebagai pembawa pesan dari komunikator menuju komunikan. Media pembelajaran adalah segala sesuatu yang dapat digunakan untuk menyalurkan pesan (bahan pembelajaran), sehingga dapat merangsang perhatian, minat, pikiran, dan perasaan siswa dalam kegiatan belajar untuk mencapai tujuan belajar.pentingnya media pembelajaran adalah alat untuk menyampaikan pesan artinya, artinya yang terpenting adalah bukanlah peralatan itu, tetapi pesan atau informasi belajar yang dibawakan oleh media tersebut. Tenaga pendidik yang mengjar disana selama ini jarang menggunakan media pembelajaran, walaupun sudah pernah menggunakan media media yang digunakan media sederhana

Selain masalah dalam pembelajaran, pendanaan pendidikan nonformal juga menjadi kendala Pesraman Widya Santhi Mandiri dan Sekha Santhi Jayanti Saraswati. Selama ini mereka mendapatkan dari bantuanbantuan sosial yang tidak mengikat. Keterbatasan dana ini juga mempengaruhi kinerja tenaga yang ada di lembaga tersebut. Selain itu aktivitas yang bisa dilakukan pun menjadi sangat terbatas.

Berdasarkan analasis situasi di atas, maka dapat dirumuskan secara operasional permasalahan yang dihadapi mitra pesraman Widya Santhi Mandiri dan Sekhaa Santhi Jayanti Saraswati adalah sebagai berikut.

1. Sumber pendanaan untuk lembaga pendidikan non formal Pesraman Widya Santhi Mandiri dan Sekhaa Santhi Jayanti Saraswati tidak ada.

2. Pesraman Widya Santhi Mandiri dan Sekha Santhi Jayanti Sarswati belum memiliki kurikulum yang digunakan dalam pembelajaran sehingga output kompetensi yang dimiliki siswanya menjadi tidak jelas.

3. Proses pembelajaran yang digunakan tidak mencerminkan pembelajaran yang kreatif, inovatif dan menyenangkan. Sehingga cenderung membosankan.

4. Tenaga pendidik yang ada belum menggunakan media pembelajaran yang mudah dipahami oleh siswanya. Selama ini media pembelajaran yang digunakan sangat sulit dipahami oleh siswanya.

5. Kegiatan-kegiatan yang dilakukan terkait dengan kebudayaan dan keterampilan belum mampu meningkatkan kompetnsi atau skill yang akan dijadikan pegangan di masa depannya. 


\section{METODE PELAKSANAAN}

Upaya pemecahan yang dapat diusulkan adalah melakukan beberapa pelatihan, pengembangan, pemberdayaan, dan pendampingan terkait dengan kurikulum, proses pembelajaran yang inovatif, media pembelajaran, kewirausahaan, dan teknologi informasi yang khusus diterapkan pada pendidikan non formal (Pesraman Widya Santhi Mandiri dan Sekha Santhi Jayanti Saraswati). Kurikulum yang dirancang dan dikembangakan adalah kurikulum yang bermuatan kebudayaan lokal, karakter, dan kompetensi. Pembagian waktu disusun secara komprehensif dan menyeluruh. Kebudayaan lokal yang dimaksud adalah kebudayaan yang ada di daerah tersebut. Budaya yang cocok diterapkan disana adalah genjek, budaya ritual, dan budaya dansil. Sedangkan pembentukan karakter yang dimaksud adalah adalah proses internalisasi nilai nilai moral kemanusiaan. Nilai-nilai tersebut dikelompokkan menjadi tiga bagian yaitu nilai etika pribadi, nilai etika sosial dan nilai etika ketuhanan. Nilai-nilai tersebut akan diintegrasikan dalam dan selama proses pembelajaran. selain itu kompetensi yang yang dikembangkan adalah kerajinan lontar, kerajinan kayu, seni lukis, seni suara, dan kewirausahaan. Pengembangan inovasi pembelajaran bertujuan membuat pembelajaran menjadi lebih inovatif, kreatif dan menyenangkan. Inovasi pembaharuan pembelajaran muncul dari perubahan paradigma pembelajaran. Acuan paradigma pembelajaran adalah hasil refleksi terhadap eksistensi paradigma lama yang mengalami anomali menuju paradigma baru yang diduga mampu menyelesaikan masalah pembelajaran. dalam proses pembelajaran paradigma baru pembelajaran seyogyanya lebih menyediakan proses untuk mengembalikan hakikat pebelajar ke fitrahnya sebagai manusia yang memiliki segenap potensi dalam mengembalikan kemanusiannya.
Memberikan materi
kewirausahaan dirahapkan dapat menumbuhkan jiwa kewirausahaan di lingkungan Pesraman Widya Santhi Mandiri dan Sekhaa Santhi Jayanti Saraswati. anak-anak yang belajar di lembaga ini juga diharapkan memiliiki jiwa kewirausahaan dan mampu membuka usaha sendiri. Selain itu, Kedepannya diharapkan mampu membuka unit usaha mandiri sebagai sumber penghasilannya. Misalnya dengan membuka unit usaha koperasi yang dapat membantu menjual hasil kerajinan yang dibuat sendiri oleh lembaga tersebut. Sehingga dapat pendanaan lembaga akan terbantu dan aktivitas-aktivitas dan program kerja lembaga pun akan berjalan.

\section{Selain}

melakukan pengembangan dan pembinaan selanjutnya akan dilakukan pemberdayaan berdasarkan SDM yang ada dan Kurikulum yang sudah dirancang. Pemberdayaan dilakukan dengan melakukan praktek langsung terhadap kurikulum yang sudah dibuat. Pada saat ini akan dilakukan kerja sama dengan sekolah-sekolah modern yang bertaraf internasional. Seperti sekolah diatmika sebagai parter dan sharing pendidikan. Selama pemberdayaan akan dilakukan pendampingan dan suvervisi klinis secara intens. Proses transfusi IPTEK (IbM) secara sistemik dilakukan dengan model pemberdayaan menggunakan pendekatan PALS (Participatory Action Learning System). Prinsip dasar dari model PALS adalah pelibatan Pesraman Widya Santhi Mandiri dan Sekhaa Santhi Jayanti Sarswati sehingga membentuk suatu sistem interaksi pembelajaran masyarakat secara partisipatif, baik secara personal maupun komunal dalam pendidikan non formal di daerah terpencil. Secara schematik, metode pelaksanaan IbM pengembangan dan pendampingan pendidikan di daerah terpencil di desa Tianyar Tengah dapat ditunjukkan pada gambar 3. 
masing-masing dusun di desa Tianyar dikoordinir oleh I Wayan Widiana dan I Ketut Mertha selaku pembina kelompok tersebut.

Program yang kami rancang dan usulkan untuk diselenggarakan di desa Tianyar memperoleh apresiasi yang sangat luar biasa dari Pemerintah Desa setempat beserta jajarannya. Mengingat baru pertama kali desa Tianyar disasar kegiatan pengabdian dengan melibatkan warga masyarakat untuk mampu diberdayakan melalui kegiatan sosialisasi dan pelatihan dari pihak LPM UNDIKSHA. Secara langsung dengan penuh penghargaan dan penghormatan Kepala Desa beserta staf menyambut kami dengan tangan terbuka dan mengucapkan terima kasih kepada LPM UNDIKSHA karena sudah bersedia memfasilitasi warga desa tianyar dengan penerjunan staf ahli yang berkompeten melalui penyelenggaraan kegiatan P2M. Harapan dari output program P2M yang tim pelaksana selenggarakan dan dharmakan kepada warga masyarakat yang dalam hal ini diwakili oleh pesraman Widya Santhi Mandiri dan Sekha Santhi Jayanti Saraswati desa Tianyar Kecamatan Kubu kabupaten Karangasem.

\section{Gambaran Umum Pelaksanaan Kegiatan P2M}

P2M ini dilaksanakan pada bulan juni 2014 di Wantilan pesraman widya santhi mandiri desa tianyar kecamatan kubu dengan mendatangkan tim pakar dari Undiksha Singraja dengan kualifikasi akademik, diantaranya pengembangan kurikulum, media pembelajaran dan manjemen dan organisasi. Sedangkan dari pihak kecamatan Kubu mendampingi dari pihak pendidikan dan kebudayaan, dan keagamaan.

Adapun alur pelaksanaan program IbM ini dimulai dari, 1) Tahap persiapan, yang terdiri dari tahap : (a) penyiapan bahan administrasi sesuai dengan kebutuhan pelaksanaan sosialisasi, (b) melakukan koordinasi dengan pesraman Widya Santhi Mandiri dan Sekha Santhi Jayanti Saraswati desa Tianyar Kecamatan Kubu, (c) menyiapkan materi pelatihan, (d) menyiapkan narasumber yang memiliki kompetensi sesuai dengan target dan tujuan pelatihan, dan (e) menyiapkan jadwal sosialisasi menyesuaikan dengan perencanaan kegiatan yang telah terprogram, 2) tahap pelaksanaan, yang terdiri dari : (a) melakukan sosialisasi pelatihan pembuatan kurikulum pesraman Widya Santhi Mandiri dan Sekha Santhi Jayanti Saraswati, penyusunan media pembelajaran dan manajemen organisasi, (b) diskusi terbatas mengenai pemahaman wawasan dan keterampilan yang sudah mampu peserta kuasai, dan 3) tahap evaluasi, yang terdiri dari (a) persentasi kesimpulan sosialiasi oleh tim pelaksana dan praktek pelatihan langsung bagi peserta, (b) refleksi berupa praktek dari pakar dengan uji coba program yang sudah dilatihkan, dan (c) memberikan penilain terhadap produk yang dihasilkan oleh peserta program IbM.

Secara umum ada 3 materi yang diberikan kepada lembaga mitra yaitu (1) pengembangan kurikulum, Pengembangan media pembelajaran penunjang kurikulum, dan (3) kewirausahaan dan pengelolaan keuangan lembaga. Dalam proses internalisasi materi, metode yang digunakan adalah metode ceramah, diskusi dengan format pendidikan non formal. Walaupun demikian, peserta yang berjumlah 20 orang yang sebagian besar merupakan guru-guru honorer di sekolah diberikan materi cetak secara lengkap. Dalam proses pelatihan dibantu dengan media/alat peraga power point yang sudah disiapkan sebelumnya. Waktu pelatihan dilaksanakan setiap minggu yang diselingi dengan monev implementasi hasil pelatihan.

Tempat pelatihan dilaksanakan di wantilan Pesraman Widya Santhi Mandiri dengan ukuran $10 \times 7 \mathrm{~m}$, sehingga nyaman dan refresenttaif dijadikan tempat pelatihan. Penilaian dilakukan mulai dari proses pembelajaran, penilaian akhir, dan penilaian pendampingan. Hasil penilaian digunakan sebagai umpan balik dan indikator keberhasilan kegiatan P2M. Penilaian proses pembelajaran dilakukan dengan menggunakan lembar observasi, lembar ini digunakan untuk mengetahui perkembangan belajar warga belajar. Selain itu lembar observasi ini digunakan 
untuk mengetahui daya ingat dan pengetahuan awal warga belajar sebelum pembelajaran dimulai. Dengan adanya lembar penilaian observasi ini akan memudahkan tutor untuk menyiapkan dan melakukan proses pembelajaran. Penilaian hasil pemelajaran dilakukan dengan menggunakan tes, baik secara langsung maupun tidak langsung. Tes yang diberikan adalah tes kalistung atau tes teori yang mengacu pada kompetensi keaksaraan dasar dan tes praktek pelatihan yang mengacu pada kompetensi kerajinan yang sudah dilatih. Penilaian pendampingan juga menggunakan observasi. Pendampingan yang dimaksud adalah pada saat mengimplementasikan hasil P2M di dalam proses pembelajaran.

\section{Hasil Pelaksanaan Kegiatan P2M}

Sesuai dengan permasalahan yang dihadapi oleh warga masyarakat Desa Tianyar kecamatan Kubu dalam kaitannya dengan upaya pengembangan wawasan pengetahuan dan keterampilan masyarakat di desa terpencil, maka program pengabdian masyarakat ini dilakukan dalam bentuk transfer iptek yang dilakukan berupa sosialisasi, pelatihan, dan pendampingan kepada pesraman Widya Santhi Mandiri dan Sekha Santhi Jayanti Saraswati yang memiliki tujuan mengembangkan seni budaya daerah setempat yang semula menggunakan kurikulum konvensional sehingga hasil pembelajarannya menjadi tidak optimal. sehingga dikembangkan melalui 1) pelatihan penyusunan kurikulum pesraman, 2) Pelatihan pembuatan media pembelajaran penunjang kurikulum, dan 3) Pelatihan kewirausahaan dan Pengelolaan keuangan lembaga.

\section{Pelatihan Penyusunan Kurikulum Pesraman}

Dalam pelatihan ini menjelaskan tentang Pengertian, Kedudukan, Fungsi dan Kurikulum Pasraman. Luaran dari kegiatan ini adalah adanya Struktur Kurikulum Berbasis Keagamaan Hindu di Pasraman Pesraman Widya Santhi Mandiri. Adapaun struktur kurikulumnya adalah sebagai berikut.

Table 1. Struktur Kurikulum Pesraman Widya Santhi Mandiri

\begin{tabular}{|c|c|c|c|c|c|c|c|c|c|c|c|c|c|}
\hline No & Mata Pelajaran & \multicolumn{6}{|c|}{ Tingkat Dasar } & \multicolumn{3}{|c|}{$\begin{array}{c}\text { Tingkat } \\
\text { Menengah }\end{array}$} & \multicolumn{3}{|c|}{ Tingkat atas } \\
\hline \multicolumn{2}{|r|}{ Keagamaan } & I & II & III & IV & V & VI & VII & VIII & IX & $X$ & $X I$ & XII \\
\hline 1 & Sruti & 5 & 5 & 4 & 4 & 4 & 4 & 3 & 3 & 3 & 2 & 2 & 2 \\
\hline 2 & Smerti & 1 & 1 & 2 & 2 & 2 & 2 & 2 & 2 & 2 & 2 & 2 & 2 \\
\hline 3 & Sradha & 1 & 1 & 1 & 1 & 1 & 1 & 1 & 1 & 1 & 2 & 2 & 2 \\
\hline 4 & Susila & 2 & 2 & 2 & 2 & 2 & 2 & 2 & 2 & 2 & 2 & 2 & 2 \\
\hline 5 & Catur Marga & 4 & 4 & 4 & 4 & 4 & 4 & 4 & 4 & 4 & 4 & 4 & 4 \\
\hline 6 & $\begin{array}{l}\text { Itihasa dan } \\
\text { Purana }\end{array}$ & 1 & 1 & 1 & 1 & 1 & 1 & 2 & 2 & 2 & 2 & 2 & 2 \\
\hline \multicolumn{14}{|c|}{ Adat Istiadat } \\
\hline 7 & $\begin{array}{l}\text { Kterampilan } \\
\text { Mejejaitan }\end{array}$ & 4 & 4 & 4 & 4 & 4 & 4 & 4 & 4 & 4 & 4 & 4 & 4 \\
\hline \multicolumn{14}{|c|}{ Keterampilan Pilihan } \\
\hline
\end{tabular}




\begin{tabular}{|c|l|c|c|c|c|c|c|c|c|c|c|c|c|}
\hline 8 & \begin{tabular}{l} 
Bahasa Inggris, \\
$\begin{array}{l}\text { Yoga, } \\
\text { kewirausahaan, } \\
\text { jurnalistik, } \\
\text { olahraga, } \\
\text { beladiri, politik } \\
\text { dan } \\
\text { kepemudaan }\end{array}$ \\
\hline Jumlah
\end{tabular} & - & - & - & - & - & - & - & - & - & - & - & - \\
\hline
\end{tabular}

Sedangkan photo-photo kegiatan pengembangan Kurikulum Pesramana Widya Santhi Mandiri dan Sekaa Santhi

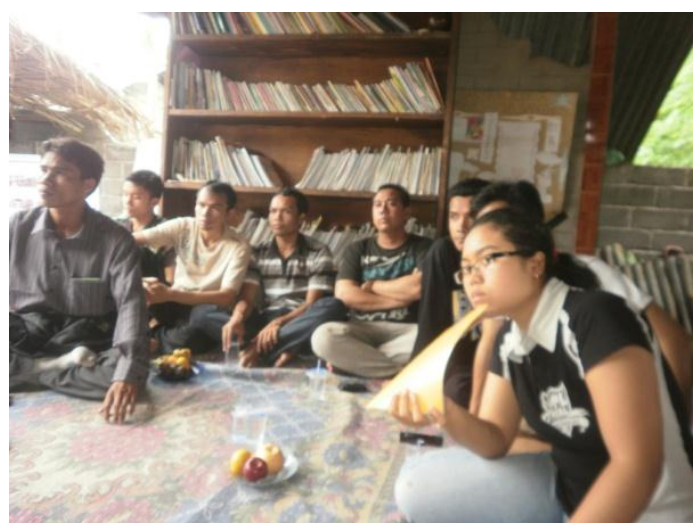

Jayanti dan proses implemkentasinya adalah sebagai berikut.

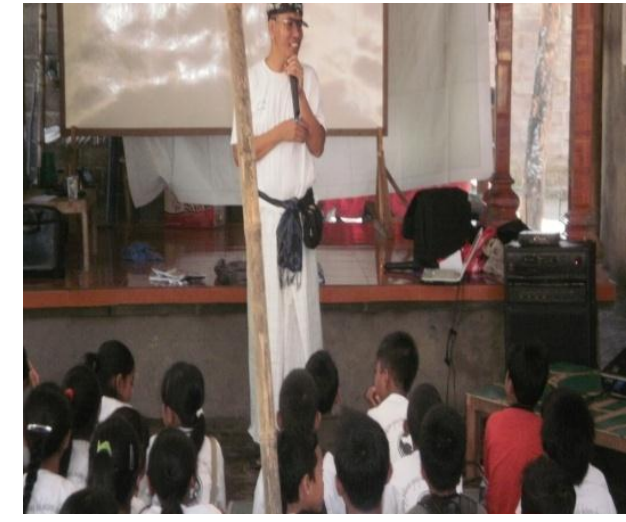

Gambar 1. Proses pengembangan Kurikulum

\section{Pelatihan Pembuatan Media Pembelajaran Penunjang Kurikulum}

Dalam pelatihan pembuatan media pembelajaran, materi yang disampaikan adalah media pembelajaran berbasis pendidikan non formal. Materi ini disampaikan oleh Dra. Desak Putu Parmiti, M.S. Materi ini menjelaskan tentang bagaimana mengembangkan potensi yang ada menjadi media pembelajaran. Pada saat penyampaian

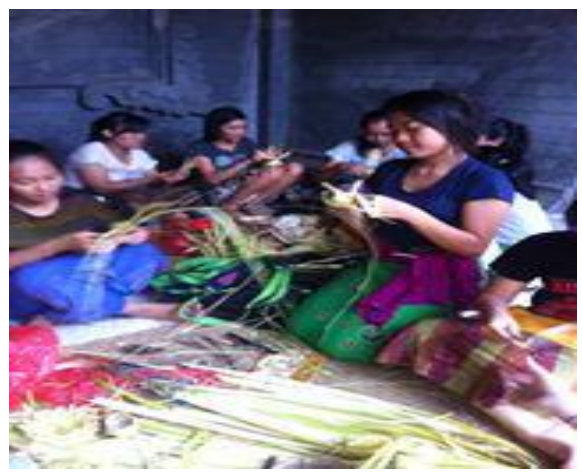

materi, peserta pelatihan langsung diajak untuk membuat media pembelajaran berdasarkan kurikulum yang sudah dikembangkan. Terdapat 3 jenis media pembelajaran yang akhirnya terbentuk sampai pelatihan selesai. (1) media pembelajaran keagamaan, (2) media adat istiadat (sains), dan (3) media pembelajaran bahasa. Ketiga proses pembuatan media pembelajaran tersebut dapat dilihat pada gambar berikut ini.

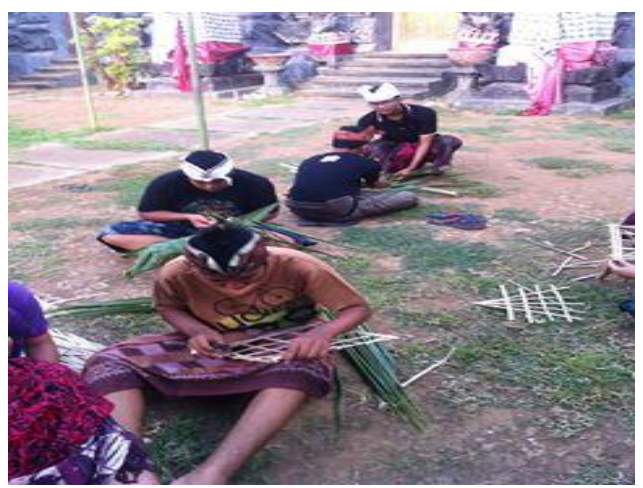



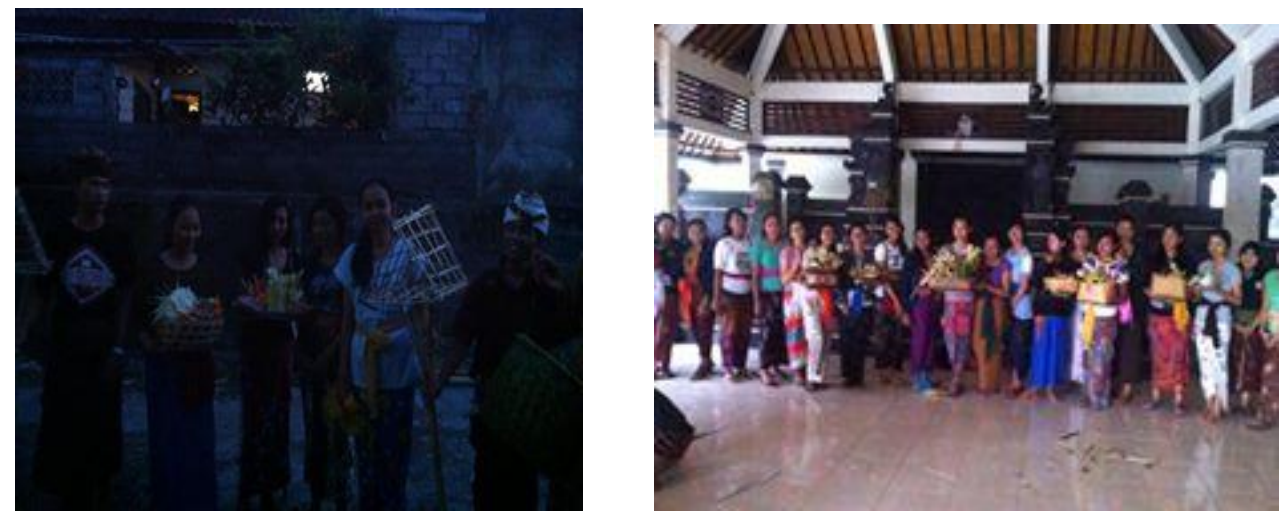

Gambar 2. Proses Pembuatan Media Pembelajaran Keagamaan Dan Adat Istiadat

\section{Pelatihan Kewirausahaan Dan Pengelolaan Keuangan Lembaga}

Dalam pelatihan kewirausahaan dan pengelolaan keuangan lembaga menyampaikan tentang kewirausahaan mandiri berbasis kearifan lokal. Karena banyaknya bahan lontar yang ada di desa Tianyar, maka kewirausahaan yang ditumbuhkembangkan adalah kewirausahaan berbasis daun lontar.

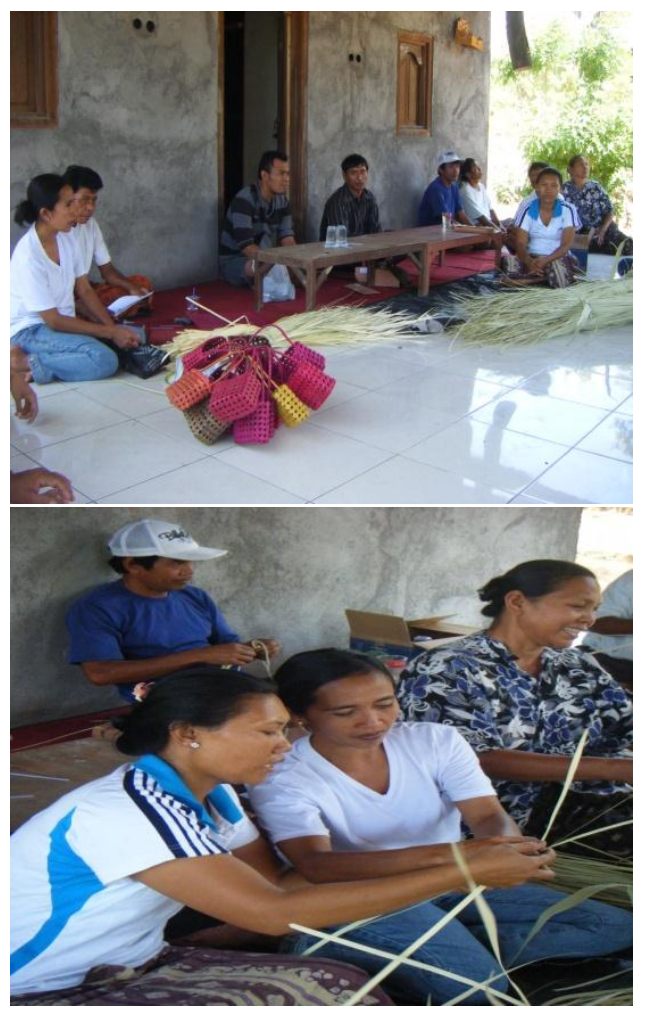

Pengurus dan guru-guru yang ada di pesraman Widya Santhi Mandiri di ajak untuk berwirausaha baik secara individu maupun kelembagaan. Secara kelembagaan terbentuklah koperasi Werdhi Sedana yang bergerak dibidang serba usaha. Koperasi ini nantinya akan menjadi Showrooom kerajinan berbasis lontar. Berikut dokumentasi kegiatan pelatihannya

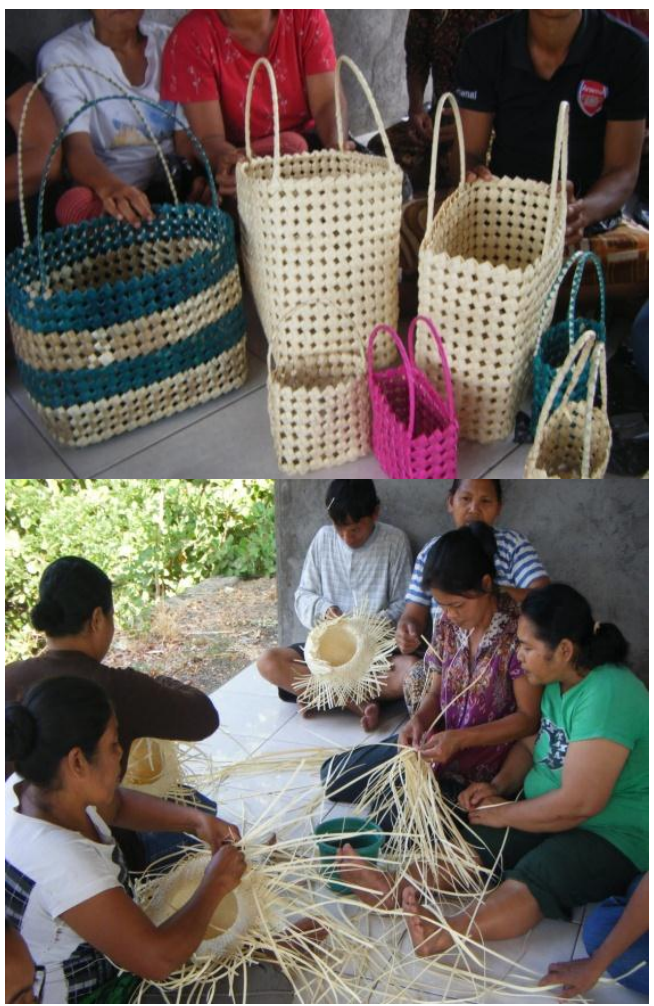

Gambar 3. Proses pembelajaran kerajinan sebagai skill dalam berwirausaha kerajinan lontar 


\section{Tahap Evaluasi Program}

Untuk mengukur tingkat keberhasilan kegiatan yang telah dilakukan, maka akan dilakukan evaluasi minimal 3 (tiga) kali, yaitu evaluasi proses, evaluasi akhir, dan evaluasi tindak lanjut. Kegiatan evaluasi ini akan melibatkan tutor/pakar dari Undiksha Singaraja. Kriteria dan indikator pencapaian tujuan dan tolak ukur yang digunakan untuk menjastifikasi tingkat keberhasilan kegiatan Setelah diberikan sosialisasi oleh tim pelaksana dari Undiksha Singaraja, pesraman Widya Santhi Mandiri dan Sekha Santhi Jayanti Saraswati di Desa Tianyar Kecamatan Kubu dapat memahami dengan jelas materi sosialisasi dan pelatihan mengenai kurikulum, media pembelajaran dan manajemen organisasi.

Berdasarkan hasil evaluasi tidak lanjut juga terekam, beberapa manfaat praktis yang diperoleh oleh pesraman Widya Santhi Mandiri dan Sekha Santhi Jayanti Saraswati Desa Tianyar Kecamatan Kubu melalui kegiatan ini yaitu: (1) mereka mendapatkan informasi yang jelas dan utuh mengenai hakekat pemberdayaan masyarakat dari segi pengetahuan dan keterampilan, bermakna untuk mengembangkan kurikulum, media pembelajaran dan manajemen organisasi yang sifatnya inovatif; (2) pesraman Widya Santhi Mandiri dan Sekha Santhi Jayanti Saraswati yang menjadi peserta pelatihan memperoleh gambaran yang jelas mengenai langkah pengembangan kewirausahaan lembaga; (3) peserta pelatihan juga mendapatkan gambaran yang jelas dan utuh tentang pengembangan seni budaya daerah.

\section{Kendala dan Tindak Lanjut yang harus Dilakukan}

Kendala pelaksanaan program adalah sulitnya meminid waktu untuk pencapaian kesepakatan pelaksanaan kegiatan, karena umumnya peserta latihan terbentur dengan rutinitas pekerjaan harian yang menunjang perekonomian keluarga, maupun pelaksanaan kegiatan ritual adat-istiadat yang lumayan padat di Desa Tianyar dalam kaitannya dengan paruman desa adat untuk penyelenggaraan ritual keagamaan sebagaimana layaknya masyarakat Hindu Bali pada umumnya. Jadi, untuk bisa mengkoordinir warga perlu koordinasi intensif dengan pihak kesra dan segenap jajarannya.

Berkaitan dengan pengkondisian peserta program, walaupun dijumpai kendala masalah waktu selama tim pelaksana program mampu mengatasinya dengan melakukan koordinasi secara intensif dengan Kepala Desa Tianyar, staf Kesra Desa Tianyar, dan segenap jajaran terkait termasuk Dinas pendidikan dan keagamaan Kecamatan Kubu serta pesraman Widya Santhi Mandiri dan Sekha Santhi Jayanti Saraswati. Karena program masing berlangsung masih banyak terdapat kekuarangan-kekurangan yang ada dalam pengabdian ini. Terutama untuk mengukur keberhasilan pengimplementasian dari kurikulum yang sudah dirancang.

\section{Kesimpulan Dan Saran}

Kesimpulan yang dapat diperoleh dari pelaksanaan program pengabdian kepada masyarakat "IbM Pendidikan di Desa Terpencil" di pesraman Widya Santhi Mandiri dan Sekha Santhi Jayanti Saraswati, adalah: (1) Tingkat partisipasi yang tinggi dari mitra program pengabdian kepada masyarakat memberikan dampak positif bagi pelaksanaan program, terlihat dari pelatihan dan pengembangan kurikulum, pembuatan media pembelajaran dan manajemen organisasi. (2) Pelaksanaan program mampu menghasilakan luaran-luaran yang diharapkan oleh program pengabdian kepada masyarakat ini, kecuali hasil pembelajaran yangmasih menunggu selesainya kurikulum terimplementasikan dan jiwa kewirausahaan yang masih dalam proses pembelajaran.

Tingginya kreatifitas pesraman Widya Santhi Mandiri dan Sekha Santhi Jayanti Saraswati mengembangakn kurikulum, mengembangkan media pembelajaran dan mengembangakn manajemen organisasi sehingga terus adaftif terhadap perubahan jaman. Sehingga seni budaya daerah tidak tergerus oleh budaya modern yang terus berkembang sampai saat ini. 
Daftar Pustaka

Departemen Pendidikan Nasional Republik Indonesia. Undang-undang Republik Indonesia Nomor 14 Tahun 2005 Tentang Guru dan Dosen. Jakarta. 2005.

Ibrahim, M., et al. 2000. Pembelajaran Kooperatif. Surabaya: Penerbit Unesa - University Press.

Johnson, E. B. 2002. Contextual Teaching and Learning. Califorenia: Corwin Press, Inc.

Lie, A. 2002. Cooperative Learning. Jakarta: Penerbit PT. Gramedia Widiasarana Indonesia.

Marhaeni, A. A. I. N. (2006). Menggunakan Asesmen Otentik dalam Pembelajaran. Makalah disampaikan dalam pelatihan pembelajaran bagi guru-guru SMA Negeri 1 Denpasar tanggal 19 Agustus 2006.

Marhaeni, A.A.I.N. Marhaeni (2008). Asesmen Pembelajaran Tematik di $S D$ Kelas Awal. Makalah disampaikan pada pelatihan guru Sd di Karangasesm (DBEP)

Nitko A.J. (1996). Educational Assessment of Students, $2^{\text {nd }}$ Ed. Columbus Ohio : Prentice Hall.

Popham, W.J. (1995). Classroom Assessment, What Teachers Need to Know. Boston: Allyn and Bacon.

Stiggins, R. J. (1994). Student-Centered Classroom Assessment. N.Y: Maxwell Macmillan International.

Pusat Kurikulum. 2002a. Pengembangan Silabus Kurikulum Berbasis Kompetensi. Jakarta: Balitbang Depdiknas

Sadia, Suastra, dan Tika. (2003) Pengembangan Model dan Strategi Pengubahan Miskonsepsi Siswa dalam Pembelajaran Fisika di SMU. Laporan Penelitian Hibah Bersaing, IKIP Negeri Singaraja

Savoie J.M. \& Andrew S.H. (1994). Problem-Based Learning as Classroom Solotion. Educational Leadership
Savery, John R \& Duffy, Thomas $M$. Problem Based Learning: An Instructional

Model and Its Contructivist Framework.

Slavin, R. E. 1995. Cooperative Learning Theory, Research, and Practice. $2^{\text {nd }}$ Ed. London: Allyn and Bacon.

Supriatna, N. (2007). Pendidikan IPS di $S D$. Bandung: UPI PRESS.

Winataputra, U. S. (2008). Teori Belajar Dan Pembelajaran. Jakarta: Universitas Terbuka 